\title{
KOLEDA FOR THE FUTURE - \\ TANAC DANCES FOR ALL GENERATIONS \\ INTANGIBLE CULTURE IN THE DIGITAL AGE
}

\section{TVRTKO ZEBEC}

The Koleda refers to the ritual event that takes place during the Christmas and New Year periods, with processions moving from house to house and participants expressing good wishes and collecting gifts. The Koleda of Dubašnica on the Island of Krk is special because a king and queen are chosen. The traditional tanac dance and the revival of the custom after a quarter of a century are presented in this context. The excellent levels of organization displayed by the local community, which uses digital technology to facilitate communication and keep documentation up to date more efficiently, has proven to be very important.

Keywords: ritual dance, tanac dance, Croatia, revival, digital technology
Koleda (koledovanje) je ritual v božično-novoletnem času. Zanj je značilna hoja v procesiji od hiše do hiše, pri tem udeleženci izrekajo dobre želje in pobirajo darove. Koleda iz Dubašnice na otoku Krku je nekaj posebnega, ker pri tem izbirajo kralja in kraljico. V kontekstu teh praks sta predstavljena tradicionalni ples tanac in proces obnove rituala po četrtstoletni opustitvi. Dobro organizacijo lokalne skupnosti podpira uporaba sodobne tehnologije, $k i$ omogoča lažjo komunikacijo, hkratipa zelo učinkovit način dokumentiranja, ki se je že pokazal kot zelo pomemben. Ključne besede: ritualni ples, tanac, Hrvaška, revival, digitalna tehnologija

In honour of Mirko Ramovš!

Twenty years have passed since a part of my MA thesis, a text on the theories and methods of dance research, was published in the Traditiones. The editor of that text was Mirko Ramovš. After accepting the paper, he devoted great effort and attention to meticulously processing the text, for which I am still grateful. His editorial comments served as valuable advice in improving the paper. I am therefore honoured to have received an invitation from the Editorial Board to participate in the issue of this journal that is being published in his honour. And that is not merely because of our shared interests in ethnochoreological research but also because of Mirko's broad smile and good will, as well as his pedagogical activities, which have had a lasting impact on the stage presentation of folklore dance in this part of Europe. His collaboration with my predecessors, the ethnochoreologists Ivan Ivančan and Stjepan Sremac, was of even longer duration, particularly with Ramovšs participation in the summer and winter folklore schools that Ivančan organized and conducted from the mid-1960s for leaders and dancers of folklore groups and ensembles from the region of what was then Yugoslavia. Mirko Ramovš always responded readily to invitations for collaboration, passing on theoretical and practical knowledge of Alpine Zone dances. The adept way he taught amateurs won him many admirers. We also worked together on joint performances of the student folk dance ensembles, "Akademska folklorna skupina France 
Marolt" from Ljubljana - led and mentored by for many years, - and the Zagreb "Ivan Goran Kovačić" student ensemble - of which I was also a member and was led by Milorad (Braco) Todić. The introductory song performed by the two of them and their fruitful cooperation resulted in excellent concerts that lasted long in the memory, and enabled us as performers to gain new experience and know-how. We particularly enjoyed Mirko Ramovšs inimitable choreography of Slovenian dances and songs from Rezija. A source of pleasure is the ongoing and pleasant relationship with his heirs at the Glasbenonarodopisni inštitut [Institute of Ethnomusicology] of the Research Centre by the Slovenian Academy of Sciences and Arts, which continues to enrich the academic exchange of knowledge and experience.

In the above-mentioned article in Traditiones (Zebec 1995), I discussed the historical development and traditions of diverse approaches on the part of ethnochoreologists - largely from eastern and northern Europe on the one hand, and the dance anthropologists and ethnologists from the United States of America and/or the social anthropologists of the United Kingdom on the other. In keeping with the development of research traditions, dance continues to be interpreted from different perspectives. In recent years, more space has been given to dance ethnography in the theoretical denotation of the scholarly discipline, despite the fact that today, respecting the European tradition of the discipline as a historical starting point, the group of dance researchers gathered in the International Council for Traditional Music (the ICTM) is also called the Study Group on Ethnochoreology. ${ }^{1}$ I continue to maintain that focus on the dance event itself. The dance is observed and analysed from the broadest to most immediate performance contexts and it is within that framework that tanac dances in the kolejani context in Dubašnica on the island of Krk will be discussed. In other words, the contextual approach to tanac dance research uncovers a great deal of information about the communities and traditions of the people of Dubašnica, the inhabitants of the north-western part of the island of Krk, and of the culture and tradition of the islands as a whole.

\section{THE DUBAŠNICA KOLEDA RITUAL EVENT AND THE KOLEJANI 2014/2015}

We, today's generation of working and spiritually capable people of Dubašnica, after twenty-five years, would again like to hold Dubašnica Kolejani events. In essence, the Dubašnica Kolejani is a form of intangible

Certainly exerted great influence in the design of future dance research will have the international Choremundus MA studies programme. The third cycle of professors brought together from four European universities (Trondheim - Norway, Szeged - Hungary, Clermont-Ferrand - France, Roehampton London - UK), along with guest lecturers and attending students from throughout the world. On the website of that study it states: "All four partner institutions lead established Master's Programmes in Dance Studies, the Anthropology of Dance and/or Ethnochoreology". <https://www. ntnu.edu/studies/choreomundus/consortium> 
heritage that has its roots in Dubašnica's distant past, its traditions and the culture it has inherited. The objective in organising the Dubašnica Kolejani is to revive our traditions and culture, and to entertain ourselves on a daily basis, but fundamentally we wish with all our hearts for this small part of our culture and traditions to be retained, because we are aware that when we lose that we, too, will have disappeared with that part [of ourselves]. (Cerović 2014/2015)

This quote is taken from a more expansive text by Zdenko Cerović, a member of the Organising Board of the Dubašnica Kolejani 2014/2015. ${ }^{2}$ Together with weekly meetings of the Board, a great deal of preparation and organization was carried out online from the very outset. The modern age as well as new media and modes of communication were fully embraced and, in many ways, facilitated the organization and performance of the koleda, contributing to the success in the implementation of the planned events. This will also have a bearing on the interpretation of this case study. ${ }^{3}$

Another important aspect in the observation of these koleda events is the excellent levels of organization displayed by the local community, where the media are an inseparable part in the organization of a project. Put simply, the Dubašnica Koleda can be seen as the successful completion of a project for the safeguarding of heritage at the local level. After giving a brief historical insight into the traditions of the custom, I shall return to further describe the performances to which reference is made. Just like in the above quote, almost every text about this year's koleda emphasized that the custom was being revived after an absence of twenty-five years. Although the koleda event is part of tradition and has been revived at irregular intervals, usually longer than ten years as will be mentioned later, a quarter of a century was long, even for the people of Dubašnica.

2 Zdenko Cerović is a full professor at the Faculty of Tourism and Hospitality Management in Opatija, University of Rijeka. He is also intensively engaged in local government - he is president of the Malinska-Dubašnica District Assembly and president of the Malinska-Dubašnica Tourist Board in the assembly of the county (regional) tourism community (Naši zvoni 2014)

3 I was surprised when Allegra F. Syder stated at the Symposium of the ICTM Study Group on Ethnochoreology (Korčula, Croatia) in 2000 that, from then onwards, it would be impossible to conceive of further (dance) research without the Internet. That sounded very futuristic to me at that time, although all of us had our own PCs by then and were using them intensively. Still, it seemed to me, it was one thing to use the $\mathrm{PC}$ as an aid in writing texts, transcribing material recorded in the field and compiling a data-base, but Internet research was something quite different. How would it be possible to research dance as a living performance exclusively online? However, on the basis of my own research, I was very quickly convinced of just how right Snyder had been. The example of this research also confirms the limitless possibilities of online connections, communication, documentation and research. 


\section{WHAT IS THE KOLEDA EVENT AND WHY HAS 25 YEARS PASSED SINCE THE LAST ONE?}

Koleda refers to the ritual event that takes place during the Christmas and New Year periods, with processions moving from house to house and participants expressing good wishes and collecting gifts (eggs, sausages, etc.). Kolejani is the local term for koleda and its participants, used in the villages of Dubašnica, the north-western region on the island of Krk. ${ }^{4}$ In Ivan Milčetićs indispensable study (1917), the koleda from Dubašnica and Omišalj on the island of $\mathrm{Krk}^{5}$ are described in detail, along with other examples from Croatia. It is a valuable source and provides a great deal of information about those island communities at the time of the koleda, particularly because it passes on two centuries of recollections and data. ${ }^{6}$ In the introduction to the Motivation Letter that the organizers of the koleda event posted on their society's Facebook pages, they spoke of their perception of their own native place:

\section{To be a Dubašljanin [someone belonging to Dubašnica]. That means to belong to a place that inherits its name from the $d u b$ oak-tree. That means to live in harmony with the opportunities that our native place offers, to create an existence for one's family, the foundation of future generations, and to leave some trace in time.}

After Milčetićs description from the beginning of the $20^{\text {th }}$ century, the changes that the 'new times' had brought were described at the end of that century by Ivo Milovčić, one of the long-term animators of the cultural life of Dubašnica (Milovčić 1995). He was the leader of the folklore group and occupied the role of the main organizer of the kolejani, which was filmed for public television on the basis of Beta Gotthardi Pavlovsky's scenario in $1972 / 73$.

4 The village of Dubašnica, similarly to some others in that part of the island, was once filled with stagnant pools (Šamanić 1989: 149) and died out because of malaria in the 18th century, while its role was taken over in the 19th century by the Bogovići settlement, which has now merged with Malinska. However, the parish retained the name of Dubašnica (Galović 2004), so that the name relates to the entire area with eighteen villages of one of the youngest Glagolitic Chapters on the island (Bolonić 1980).

5 The Island of Krk is one of the largest islands in the Adriatic Sea and lies in its northern part, in the Quarnero Bay. The island has been inhabited since the Neolithic Age and, through history, has been under the rule of Rome, Byzantium, Venice (on several occasions), and, since the 11th century, subject also to Croatian rulers. At that time, it was the centre of Glagolitic writing, with stone monuments with Glagolitic inscriptions attesting to this fact. Subsequently, it continued to change hands, but despite frequent alternations and the influence wrought by Venice, the Habsburg Monarchy, and France, the domestic population has remained homogenous up until the present day.

6 It is reasonable to assume that the descriptions given by Milčetić (1850-1921) and those of the parish priest, Albanež, who was Milčetićs source, date back to the beginning of the 19th century. 
The koleda in Dubašnica and Gabonjin are more complex in content than those at other places on the island of Krk. The idiosyncrasy of those koleda customs lies in the selection of a king and queen. For that reason, Milčetić interprets them to be an earlier form of the custom. The custom of selecting a king is widespread in other places among the southern Slavs; in Croatia, it is more often found on the islands and in the narrow coastal strip, although these are not necessarily connected with koleda customs. ${ }^{7}$ Thus, Milčetić links choosing a king with the Roman Saturnalia (at the end of December) and interprets this as being the result of the Saturnalia's influence in the Croatian koleda and Carnival customs. A critical reading of Milčetićs text (Škrbić 1999) reveals that this is a unjustifiably broad interpretation, and the linking of all similar phenomena in which certain 'fragments of customs' that appear are characteristic of the koleda. ${ }^{8}$ However, monitoring the intensity of this year's koleda together with choosing the king and queen, and the significance of those customs for the community of the 18 Dubašnica villages, coupled with the re-emphasis on deep-seated collective memory in renewing the custom, fully justifies Milčetićs approach in not dividing the strata of the performance ritual and his effort to present them in all the breadth of their meaning. In contemporary interpretation, we also try not to take fragments out of context or construe only 'text', structure and/or the content of individual parts of the performance. Moreover, we regard interpretation to be of higher quality when an endeavour is made to understand the entirety of the custom and its sense and/or when we manage to uncover and show the stratified nature and multiple meanings from various perspectives. 9

Milčetić (1917) believed that, as far as the island of Krk was concerned, the koleda custom had been best maintained in the Dubašnica area because of the isolation of that part of the island and the relatively low number of Glagolitic priests. Perhaps somewhat romantically, Milčetić saw the reason for the heightened interest in the preservation of various antiquaries over the other Krk kasteli, or citadels, to be found in the weak influence of foreigners and people of the Church. The people of Dubašnica were less inclined to go abroad, and so that was also referred to as an argument for their kolijani having been

There is also data in Croatia on the king being chosen before Easter, and even during summer according to some sources (Lozica 1990: 167). The data have been systematised by Milovan Gavazzi (1991: 193-200), Ivan Ivančan (1967: 155-168) and Ivan Lozica (1990: 111-118).

8 In the text on the koleda ritual, Milčetić also described the burning of bonfires at Midsummer $(\mathrm{St}$ John's Day) and at Christmas, and Carnival, the čarojice, zvezdari, surovari, dodole and prporuše, lazarice and krizari processions, and the choosing of the king and the processions of the king and queen. According to Škrbić (1999: 4), he also dealt in even more detail with the texts of the jurjaši (St George's Day) and ivanje (St John's Day) songs, songs sung accompanying the kolo-dance, the mantinjada sopela shawm player tunes, the toasts "and even the practice of carrying flowers to be blessed on Palm Sunday". Škrbić finds the reason underlying Milčetićs error in contamination - the transfer of elements of one custom into another, as well as his having had available in some cases only fragmentary descriptions of a custom.

9 I interpreted the 2004 koleda in Gabonjin (Zebec 2006) as an indication of continuity and collective memory, even when the ritual event occurs at highly irregular intervals. 
preserved in "virginal old style" (Milčetić 1917: 8). ${ }^{10}$ Another aspect was the natural fertility of that part of the island and the possibility that each of its inhabitants availed of, being able to afford acting as the king-host to the members of the kolejani procession.

According to sources, the koleda in Dubašnica were performed by young people from the feast day of St Stephen (Stipanja) up until Twelfth Night. The basic conditions were that the harvest had been a good one, since the amount of contributions for the pir, or feast, depended on that, and that a suitable person had been found to be chosen as the king (Milčetić 1917: 8). The latter involved assessment of his property and reputation, and his capability of ensuring premises for the final feasting (pirovanje) and covering all the costs associated with the feast, since these could be quite steep. ${ }^{11}$ The very name of the final celebration, the Veliki kolejanski pir [the Great Kolejani Feast] - applying the term pir that is used for wedding feasts - indicates the profound, hidden mythic and symbolic meaning of these customs and rituals. The choosing of the king was agreed upon ahead of time by the young men who informed the candidate. He would then be snatched and carried around the church on a special stool, the šedija, after the evening mass on St Stephen's Day. The queen, whose duty it was to supervize the gathering of the contributions, was simply asked to accept the position. In Dubašnica, that role was traditionally also played by a man, but he was expected to be a respected man of means, since he was himself expected to contribute generously. Collections were also made for the pir feast in order to reduce the king's expenses. Following a successful harvest, the judge and the parish priest (the plovan) would each make a gift to the kolejani of "a barilo [barrel] of wine, while the kmets (meaning master on Krk, an independent farmer) gave as much as they could" (Milčetić 1917: 14). Under the leadership of the queen, the young men sang the koledva carol songs and collected gifts through all the villages of Dubašnica during the period from St Stephen's Day to Twelfth Night. Not to be visited by the procession was regarded as an insult for a household. It was the duty of the queen to keep all the gifts and contributions for the celebratory pir feast at home (Milčetić 1917: 14).

Thus, the koleda in Dubašnica can be divided into two parts. The first is the period of collecting and gift-giving from St Stephen's Day to Twelfth Night, while the second is the

10 We can accept this claim as problematic as it is well known that several families have emigrated from the Island of Krk to the USA since the 19th century (Bozanić 2014). Families from Omišalj and Dubašnica lead in the number of around 640 families that emigrated from the whole island during the 1950s. Migrants from Dubašnica had already established their local society Dubašnica Social Club of America Inc. in New York by 1940 (Galović 2013).

11 Gavazzi (1991: 195) mentioned that the role of the king was not without its perils, because in his desire not to be outdone by his predecessor, he would completely exhausted himself whilst wining and dining, and found it difficult to recover from his exertions. It was therefore not by chance that, according to the description of the koleda in the village of St Vid-Miholjice (dating from 1928 and 1938), returnees from America were chosen because it was known that they were better off than the locals (Šamanić 2014). The king in Dubašnica in 1930/1931 was Jure Radić, whose nickname was Merikon [American] (Galović 2014). 
pirovanje [feasting], usually on the Sunday after Twelfth Night. Gifts were collected during the course of the koleda, with the singing of the carol songs or the saying of prayers (in houses that were in mourning for a lost loved one), but there was no dancing. The dance entertainment took place on the day of the pir when the participants were in particularly good spirits and dressed in their finest regalia. ${ }^{12}$

The koledaši [the carol-singers in the processions] excite not only Dubašnica but also the nearby places on Krk, so that the young people rush around, walking quickly for hours as if crazy to see them at least in the church or at the tanac-dance. (Milčetić 1917: 9)

The tanac that is performed after the mass 'in the open air' is an opportunity to bring folk together, and it is danced right up until the dinner in the presence of "the better people, especially the plovan [the parish priest], another priest or two, the teacher, the superintendent, etc." There is dancing again after the dinner, usually of the tanac, although even in Milčetićs youth "foreign dances were starting to appear: the polka, etc." (Milčetić 1917: 9).

To his description of the koleda, Ive Milovčić (1995) adds the fact that, on the occasion of choosing the king and queen, an argument could sometimes break out between the young men from the upper and lower villages of Dubašnica if they were unable to agree on a choice that would equally represent the interests of one group (the grmari) and the other (the prlipkari).

Apart from that, Milčetić stressed that they did not hold the koleda every year, and not every ten years or even twenty years; in a record from 1901 it was stated that the previous koleda ritual had taken place 18 years previously, expressing the fear that this was perhaps the last to take place on Krk (Milčetić 1917: 12). However, others did follow after the koleda that Milčetić described:

12 Niko Kuret draws a distinction between the Christmas and New Year koleda, on the one hand, and the koleda for Twelfth Night [the Feast Day of the Magi] on the other. In his opinion, as quoted by Lozica (1990: 113), the Christmas and New Year koleda continued the tradition of pre-Christian ritual processions at year's end, while the Twelfth Night koleda commenced in the 16th century as a schoolboy custom. As far as Dubašnica is concerned, Galović (2014) assumed that the custom of choosing a king derives from the Venetian period and that it is connected with the confraternities present here, their task, among others, being to nurture a Christian sense of fellowship. The Confraternity of St Nicolas, which was established in 1538, still exists in Porat (in Dubašnica) and its members meet regularly. Without well-defined organizations such as the confraternities, it would be difficult to imagine the organization of such a custom, as was noted in the Nova Sloga journal (1901) with the news that "many young men have become members of the society". In my opinion, it is precisely the Dubašnica koleda which shows how well the custom has integrated - the pir feasting on Twelfth Night is the logical culmination of the ritual and follows the service after the collection period. If other customs or influences have indeed been modified or accepted through history at various times they have become integral parts of the custom and have been maintained in Dubašnica as a unified meaningful whole, right up until the present day. That is why I incline more to Milčetićs need to describe and interpret them in the entirety of the performance, rather than treating them fragmentarily. 
After World War I, kolejani were held in 1921/22. ... The king then was ... from [the village of] Bogovići, while the queen was from Oštrobradić (there were thirty pairs of young men and young women).

In 1931/1932 the king was from Bogovići, the queen from St Anton (50 couples).

In 1939/1940 the king was from Bogovići, the queen from Ljutići (100 couples). In 1972/1973 the official king was from Malinska, his deputy from St Anton, the queen from Malinska and the deputy also from Malinska (there were 150 couples at the kolejani pir feast - the Dubašnica Folklore Group - old and young men and women, young men and girls along with 30 invited couples. (Milovčić 1995: 287-288)

The kolejani participants in 1972/1973 featured deputies for the official king and queen. This fact demonstrates how television and the situation at that time had brought about a change in tradition and the establishment of certain new circumstances that had not existed until then. Damir Kremenić (2001: 11) gave brief information about the koleda in Dubašnica in 1988/1989. He mentioned the procession around the Dubašnica villages, the symbolic donning of the king and queen in shepherd cloaks (kabani) as the old king handed over his authority to the new incumbent at the square in Bogovići, the arrival of the kolejani processions at the Hotel Palace in Malinska where a fashion show was later held, while the king set the krlj alight, something akin to a Yule log "that was to smoulder throughout the entire duration of the koledve". A joint photograph of all the participants in front of the Hotel Palace, where the kolejanski pir feast was held, preceded the pasta dinner - šurlice with ghoulash - zvacet, followed by a joint tanac.

\section{CHANGES FOR THE NEW TIME: EVERYONE FROM DUBAŠNICA IS A KOLEJAN [KOLEJANI PARTICIPANT]!}

It is clear from conversations held with participants in this year's koleda that they had had been thinking of reviving it for some time. However, the individuals who promoted the idea needed more time for their preparations. Attempts had been made earlier but, owing to unfavourable circumstances and a lack of support for the initiative, those attempts were unsuccessful. ${ }^{13}$ Another aggravating circumstance was the size of the area - all 18 of the

13 "A desire smouldered in us for many years; we whispered, asked and were aware that it must happen somewhere. In the quiet depths of the soul, we did not want some of the stories from history to be repeated. We remembered the kolejani of 1972 and 1988. We did not want the kolejani to be under pressure, with ideological characteristics, interest groups and the objectives of individuals." (Taken from a speech by Z. Cerović, member of the Organising Board during the kolejani feast at the Hotel Malin in Malinska, Island of Krk, 18.1.2015). 
villages and communities of Dubašnica had to be united around one and the same objective. Together with the majority, families and individuals who nurture tradition and have special feelings for it, there are of course those to whom it means nothing or regard the upkeep of old traditions as a sign of backwardness and are opposed to them. Thus, what is in question is not a homogenous group, but rather many small communities that it is very difficult to bring together. And there is evidence in earlier sources of the diverging interests of the upper and lower villages. ${ }^{14}$

The dinner of the kolejanski pir on January 18, 2015 was organized in the Hotel Malin in Malinska. After the king's welcoming speech and the parish priest's blessing of the participants and dinner that was served, speeches delivered by other eminent guests then followed. They explained that for the holding of the koleda the crucial was a journey of the parish choir in the foregoing year. The choir initiated the "idea" to bring together the members of the kolejani procession. Following that, an "Initiating Board" was established along with the "Organizing Board" for the purpose of choosing the members who would represent each of the villages. The 26 members of both boards met consistently, almost once a week, the idea bore fruit and "this lovely custom" was successfully organized.

In March 2014, they organized themselves into committees: for costume, funding, gastronomy, for choosing of the king and the queen and their entourage (the bearers of the banners and the king), for the media and public relations, for the programme. They also set up sub-committees - for dance (the tanac, polka, mazurka, and the prebir) and for singing (kanat). Again, the traditional fellowship and experience of bringing people together and the work of the confraternities proved to have a formal influence and to be so useful that the organizers founded the Society of the Dubašnica Kolejani, which was "open to membership for all people of good will who express the wish, interest and desire to provide support for holding the Dubašnica Kolejani in 2014/2015" (Turčić 2014). With that objective in mind, they prepared the by-laws of the organization.

In June 2014, they set up the Facebook page of the society. I would regard that step as leading to the richest source as the contemporary electronic document that speaks in detail of the excellent, well-conceived organization of the activities. At the outset, one can follow the old photographs of Dubašnica folk in traditional costumes from previous koleda (from

14 However, earlier sources did not mention that the koleda had been organised in any of the other villages in Dubašnica, such as the recently described kolejani in 1928, 1938, 1947 and 1953 in the villages of St Vid-Miholjice (Šamanić 2014). Šamanić tells us that the first kolejani in St Vid-Miholjice of which a written record exists was the one in 1928, which does not also mean that the ritual had not been held earlier. He also mentions that the queen on that occasion had been a woman, the wife of the king, rather than a man as was customary in the Dubašnica koleda. Therefore, the koleda in St Vid-Miholjice is more similar to the one in Gabonjin (cf. Zebec 2006), a village that is not part of the Dubašnica area, and so further comparisons will require additional research. In describing the 1901 koleda (Naša sloga 1901) was written that on that occasion the spacious church "was almost full with either local or foreign people from Miholjice, Dobrinj, Poljica" which indicates that Miholjice was not regarded as part of the Dubašnica area as it is today. That village became a part of Dubašnica territory in 1997, and its parish and "soul" (identity) is still independent and different from Dubašnica. 
1939 onwards). That is followed by an informative and detailed text written by Tomislav Galović about the history and significance of the koleda. ${ }^{15}$ Then people of Dubašnica writing in their own local vernacular with much drive and pride, speaking of the various types of their traditional costume, accompanied by photographs, all meant as a stimulus for renewing the costumes of the members of the koleda procession. A glossary of local terms for the individual parts of costume is attached with the intention of spurring research, so that the costumes can be renewed in the best possible manner. A favourable result followed because, along with the work of the costumes committee, a book was published (Kremenić 2015), as a handbook for costume renewal with a host of information and photographs, particularly important in the manner of folding the $r u b$ - the specific female head-dress for festive occasions. There were multiple hits on electronic social network in connection with preparing the costume exhibition - with samples that could be followed in renewing old and acquiring and sewing new ones. ${ }^{16}$

Delighted comments came in from emigrants from Dubašnica living in Argentina, America, Australia, Germany, Austria and Zagreb, as well as contacts with those who had returned to their native place from America. ${ }^{17}$ Along with every feast day that is announced on Facebook by the Society, photographs are posted of fellow citizens in costume, firstly from the archives of the Tourist Board, and then at the suggestion of the organizers to participate in a competition with prizes for many of the local folk responding with photographs from their own archives. Memories of parents and the older generation stimulate the spirit of renewal and act as a homogenous factor. Similar examples of web-pages and interactive social network confirm the efficacy and range of the digital aid in recent humanistic and dance research projects (Niemčić 2015). Verses are written in the local vernacular or diffused personally, speaking of the beauty of their speech, the specific nature of the historical Glagolitic script, the songs, the music played by the sopele (shawm) musicians,

15 Galović is a historian (an assistant professor at the Faculty of Humanities and Social Sciences, University of Zagreb), closely linked with his homeland Dubašnica in his professional and humanitarian work. At the beginning of December 2014 he gave a lecture entitled "Introduction to the Dubašnica Kolejani" in which he presented all the important elements of this custom. He ensured that the people of Dubašnica had access to all the important sources that could help in the revival of the custom, such as digitized old films on YouTube or the article from Naša sloga from 1901, whose author he thought had probably been the priest, Mužinić Mužina.

< http://www.malinska.hr/uvodnik16.html> (accessed in September 2015).

16 A news item on Facebook and an advertisement with a price list spoke of 31 complete costumes and a host of individual part of costume and jewellery having been ordered and made after the first exhibition in August 2014. A new exhibition followed in September and it was possible again to order the making of costumes. According to Ivo Šabalja, president of the Society and the Organising Board, who deserved the most credit for the successful mobilization of the entire Dubašnica area and the organization of the kolejani, a total of as many as 200 costumes were made on that occasion (Trinajstić 2015).

17 A great deal can really be read and learnt about the people of Dubašnica by following the comments of individuals and their profiles. 
and the dance. Photographs of performances by older folklore groups also serve as a form of encouragement, with the hope for the new revival and training of the younger generations - so they do not forget! Digitized film clips of parts of the koleda in 1972/1973 and 1988/1989 can be seen on YouTube and are shown on the Facebook pages. Special design and Glagolitic script is used to advertise and to thank early sponsors.

From autumn and the beginning of the school year, invitations go out in the same way to attend "a school of the tanac, the polka and the mazurka", to learn the traditional dances that will be performed twice a week during the entire quarter year, the final objective being to remind attendees of the traditional dances or to teach them fully to 200 couples. The singing of the Old Slavic Glagolitic mass is being revived with the church choir, and a recording of "The Koleda Procession Has Arrived at Your Home" is being made to be promoted with a book about the costumes by Kremenić on the day before the pir on 17. 1 . 2015 in the Bracera Tavern in Malinska (owned by the Šabalja family).

There is no mention in old sources of dancing on St Stephen's Day when the "king is being elevated" after the mass and the choice of the queen is announced with the symbolic donning of the kaban - a traditional shepherd's cloak of čoja stout peasant cloth (pressed wool) with a hood. However, all the former members of the folklore groups in the past, organized by generations, were invited to gather so that they could be at the head of the festive procession. Going to the large school sports hall was announced in the programme for the celebration of St Stephen's with the promulgation of the king and queen after the mass, and as many as six generations of the Dubašnica folklore groups performing the dance there.

A survey was made of the number of people interested in joining in the dinner at the kolejani pir so that efficient planning could be carried out. A call was made for sponsored contributions (in food, drink and cash), followed by a "Motivational Letter" in the name of the Organising Board, printed in the district newsletter and available on the Facebook page. ${ }^{19}$ All of Dubašnica's new inhabitants were invited "to integrate themselves, to help

18 The island of Krk is also known for its organization of the island folklore festival since 1935. It is the oldest festival in Croatia (Pavačić 2005). The islanders organised it for tourists, and it has been maintained until today. The Festival is shown to be one of the important venues for prominently featuring the characteristic symbols of the island communities, which are more important to them than to the tourists. Mutual observation and evaluations of the folklore group performances is a way of testing their current status. It is also one of the indicators of the relations in the community in which the group is active. In the island environment in the context of the Festival, such stimuli are very beneficial, since, without the criticism and validation of the onlookers, there can be no authentic enjoyment in the tanac (Zebec 2005: 328).

19 "And so, when we put on our traditional costumes, start to dance the versa or sing out 'the music notes in our very own way' [po domaću], we awaken the 'spirits of our forebears' in ourselves. Then we become a visible sign of the duration of the human community that long ago, very long ago, embraced Dubašnica as its home... Let there be feeling for the place where we were born, our native place, [with] thanks for and pride in everything that has been left to us by those who came before. Let us be proud, let us guard our treasure and make a gift of it to our descendants..." 


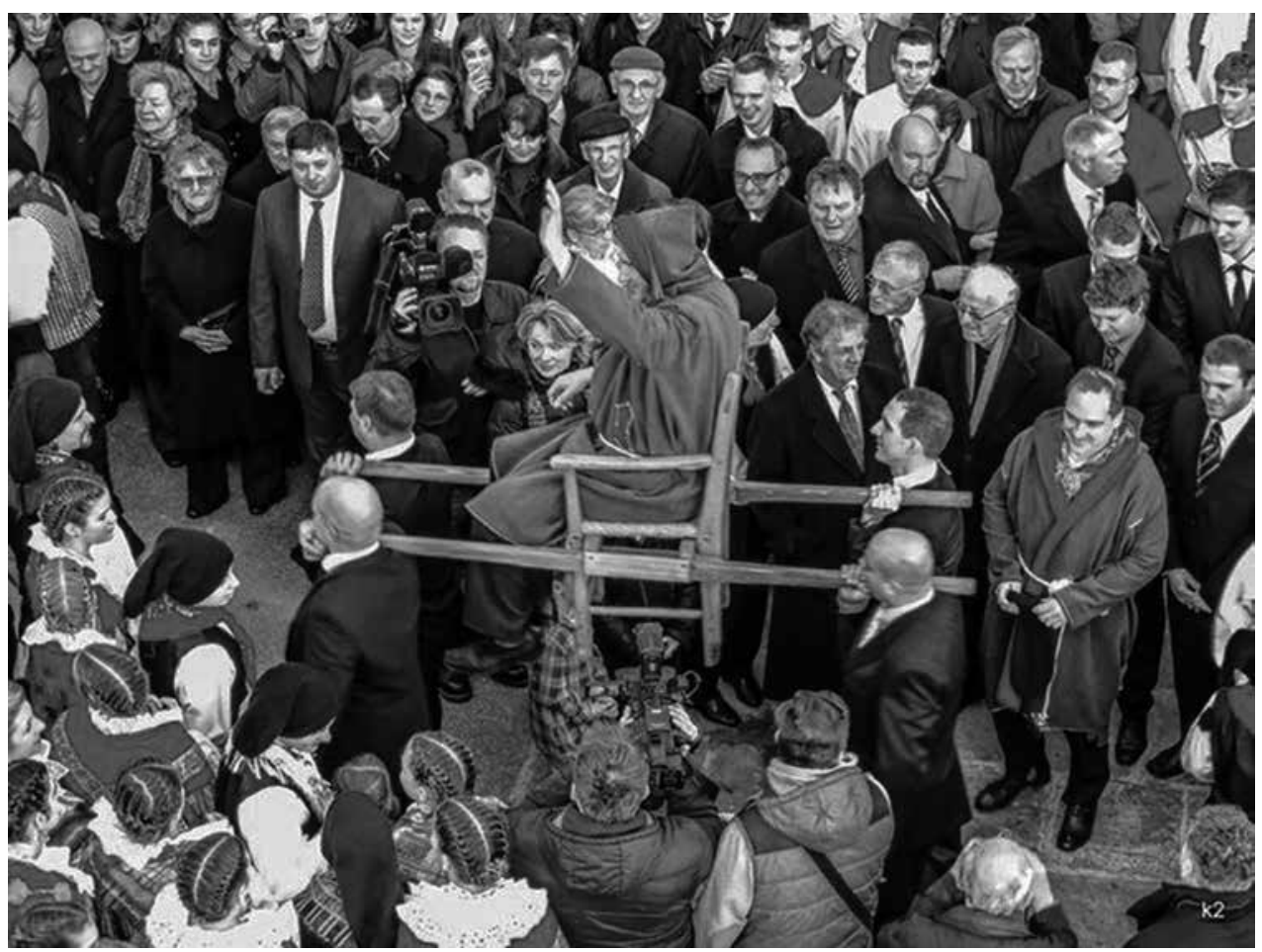

Elevating the king. The male queen is behind the king in kaban. Photo: Krunoslav Kaurić, Malinska, from Dubašljanski kolejani Facebook page <http://tinyurl.com/odkojps>.

to retain our culture - our ancient past, so that you, too, can discover a 'new' culture, to which you basically wish to belong, since you have decided to live with us, and we want to accept you" (Cerović 2014/2015). ${ }^{20}$

After the proclamation of the king and queen on St Stephen's Day, other important days are the koleda processions around the villages. Following the blessing of the Guardian of the Franciscan Monastery in Porat, the kolejani led by their male queen, Ivica Žgombić, visited 18 villages from 2-16 January, 2015 sharing that blessing, with the good wishes of the heads of the households and mutual gift-giving. In the words of the king, Tomislav Dujmović, all of this was "bringing people together - so that they could wish each other well and exchange gifts". In other words, in the majority of cases the heads of the households give gifts to the members of the procession, while in the case of their coming to less well-off fellow villagers, the koleda participants leave them gifts with their good wishes. They are proud of that charitable and humanitarian note in their mission that they have

20 It is emphasised in the kolejani by-laws that the families of the king, the queen and the immediate circle of important persons such as the banner-bearer must have been Dubašnica folk for generations. Something similar, but not so strictly, is also expected of the members of the koleda procession; since there are many married couples with one member having moved into Dubašnica on marriage, these by-laws do allow them to participate on an equal footing. 
inherited and wish to pass on to their young people. ${ }^{21}$ Aware that a lot of cakes will be left after the kolejani pir, they made arrangements ahead of time to take them to the nearby city of Rijeka to the society of the homeless. During the procession, the role of the queen is the most important one. "He should know how to dance and to sing and must be wellloved among the folk!"22

\section{THE TANAC DANCE IN THE KOLEDA RITUAL}

Tanac is a traditional dance, practised in rural communities all over the island of Krk at various public gatherings, such as weddings, days dedicated to local patron-saints, carnivals, and koleda rituals. By its characteristics, the tanac differs from all other dances on the island, which consist mostly of polkas and mazurkas. The force and power of dance as a means of expression and communication is fully manifested in the tanac. Competing with each other in front of the musicians, the dancers impose themselves upon the musicians. The musicians evaluate the qualities of the dancers and set the duration of this competition by changing the musical themes. In this way, the dancers display their abilities to other participants in the tanac and to all those who have gathered to watch. Individual improvised movements and gestures play an important role. By shaking their raised arms during the spontaneously improvised steps, the prebir, and by shouting out messages to the sopci musicians, the dancers reveal their feelings as well as their physical and motor abilities. This kind of communication between dancers and musicians usually results in more agitated music-making, as seen in the musicians' beating on the floor with their feet. The individual's possibility of expression is greater in the tanac than in other dances. It is not just the physical movements that are expressive. The energy that appears in the creation of a movement is an exceptionally important form of expression in the tanac. It has a liminal characteristic in van Gennep's terms (1960), a trait that allows the performers a temporary change in social rules. A better performance evokes a more favourable evaluation from onlookers. In this way, the dancer in question attains or confirms his or her standing in the community. The dancer's reputation is an important consideration, as the best dancers, the tancaduri, always lead off the tanac. These are the dancers from whom others could well learn (Zebec 2005: 324).

21 "The koledva nurtures the feeling for helping others, especially the old and infirm, but that should not take place only at koledve time but rather throughout the entire year that has 365 days. /.../ let the young people learn that /.../ by doing that you have lengthened his day and his life. /.../. it means a lot to them. /.../ they have been joined to us. /.../ - the motto is: and I am the one who is with you" (from an interview with the king on 18.1.2015).

22 According to the words of the kolejani processioner Danijel Šabalja in an interview for the R TV Channel's News, broadcast on 29. 12. 2014 <https://www.youtube.com/watch?v=Rm-MciUHrbo> (accessed in August 2015). 
These are the certain preconditions that should be known about the tanac as a dance performed on Krk, especially when it is performed in the koleda ritual. During the koleda in Dubašnica in 2014/2015, it was planned from the outset that on St Stephen's Day, immediately after the king and queen had been chosen, all of the kolejani participants would go to the school's sports hall, led by the sopci musicians and members of as many as six folklore groups from the Dubašnica area, made up of all the generations. Although descriptions from existing sources have not yet indicated that there was a joint tanac on St Stephens's Day when the king and queen were chosen in the past, the organizers assessed that the occasion should be made grander at the moment when authority is handed over from the old king to the new. Therefore, the king's speech to the people of Dubašnica was followed by his tanac, which was led off by the king with four female partners, followed by the queen with her two partners and the other dancers with their partners. It is only in Dubašnica on Krk that the first dancers - in this case, the king who leads off the dance - can have four, and if desired and needed, six female partners in the tanac - with two or four on each side. This time, too, as in a series of other traditional events, the tanac has shown that it is performed as the pinnacle of celebration and ritual.

The basic characteristic of all the island tanac dances, and shared by those of the broader cultural area of the northern Adriatic, is the brisk interchange of small steps, called prebir. The prebir motif is incorporated into the dance in various ways. Along with the style differences by which the tanac dances can be classified according to dance vernaculars, dialects and/or idioms, they also differ in the structure of spatial formation - the way the performers move through the venue. All the dances consist of several traditional firmly set parts, or versi. Some parts can (and must!) be repeated during one particular performance of the tanac, even several times (usually three), while others are performed only once. That depends, of course, on the local tradition and the moment or context of the performance.

Apart from the prebir steps, the circular movement through the dance venue with changes of direction in front of the sopci are typical of all tanac dancing. The usual movement direction is clockwise (to the left from the sopci).

The second method of spatial formation is in couples or trios and/or one man with several female dancers in Dubašnica. The basic feature of this part of the tanac is the change in the dancers' direction of movement which always occurs in front of the sopci- the dancers have to move across the square (prekriži se placa or udela ključ).

The third method of spatial formation of the tanac is dancing in two facing rows women on one side and men on the other. The basic characteristic of that part of the tanac, which is performed in two rows, is the tiny intertwining prebir step. The men take larger steps, moving backwards and forwards in their row, in which the female dancers in their row follow them, so that they are always facing the men. Throughout this proxemics, it is possible to read the social relations and gender differentiations of the dancers from the dancers' mutual bodily relationships and behaviours. There is an obvious patriarchal social model. The men are always more prominent. They always lead the tanac. All the other 
dancers follow the first. He is the one who can invent or change the figure and his female partner has to follow him. On the other hand, he is the one who cares about her and gives her full support and security (cf. Zebec 2005: 332-335).

All generations in Dubašnica practised their tanac for three months. They performed it first on St Stephen's Day, and the second time on the day of the grand kolejanski pir feast. On that day, as it had been on St Stephen's, the tanac was the culmination of events. In the morning, a mass of 400 festively dressed kolejani processions gathered on the Riva, or quayside, in Malinska to form a procession. It was led off by a bandira, or flag-pole (more than 5.5 metres tall on that occasion), made of a specially chosen tree that was said to have grown for 25 years, probably alluding to the long period that had elapsed since the previous koleda. Some 50 silk scarves were tied to it, with a round bun, a kolac bun at the top, together with an apple. ${ }^{23}$ The kolejani procession was led, in keeping with tradition, by sopci musicians who constantly played sopele, the large and small shawms, and were followed by the king and queen and their spouses, and then the members of the procession, starting with the older couples down to the very youngest. It took some time to put together the procession in the cove that is Malinska's harbour, where a group photograph was also taken. Then the procession set out to attend the mass in the parish church of St Apolinar in Bogovići. During the concelebrated mass served by three priests, the choir sang the revived Glagolitic tunes. After the mass, as on St Stephen's Day, all the kolejani participants went to the sports hall where all six folklore groups performed their tanac. This time, too, of course, the honour of leading the first tanac went to the king and queen with their female partners and their generation of kolejani, the so-called kumpanija.

After the first dance, they were joined by other kolejani, largely the older couples who enjoyed several polkas and mazurkas. All the generations of dancers follow in order so that, overall, with the tanac alternating from time to time with polkas and mazurkas, it lasted for a full two hours. ${ }^{24}$ It was interesting to monitor the stylistic and structural differences in the tanac as danced by the individual generations. Those differences have resulted from the influence of individual leaders of the dance groups, who have changed as time passed. The Dobrinj tanac, which they call tonoc in their local vernacular, differs from the one in Dubašnica. For a brief period, one of the young Dubašnica groups learnt to dance from a female leader who knew the neighbouring, Dobrinj variant of the tanac. That is why this generation of young Dubašnica dancers still performs the tanac today in a

23 Similar banners with particular symbols are carried in wedding guest processions or for major church feast days as in the Stomorina [the local term for the Virgin] manifestation in Omišalj, held in honour of the Assumption Day of the Blessed Virgin Mary. As noted in early sources, the participants also carried the Croatian national flag with the great banner.

24 The derivation of the word tanac is ambiguous. The entire dance event can be a tanac (idu na tanac 'they are going to a dance'), and when they say that they dance during such an event (tancaju tanac 'dance the tanac'), the Krk islanders are referring to the actual dance. Islanders also use the term tanci to refer collectively to all the dances they know, such as in this case (Zebec 2006: 98). 


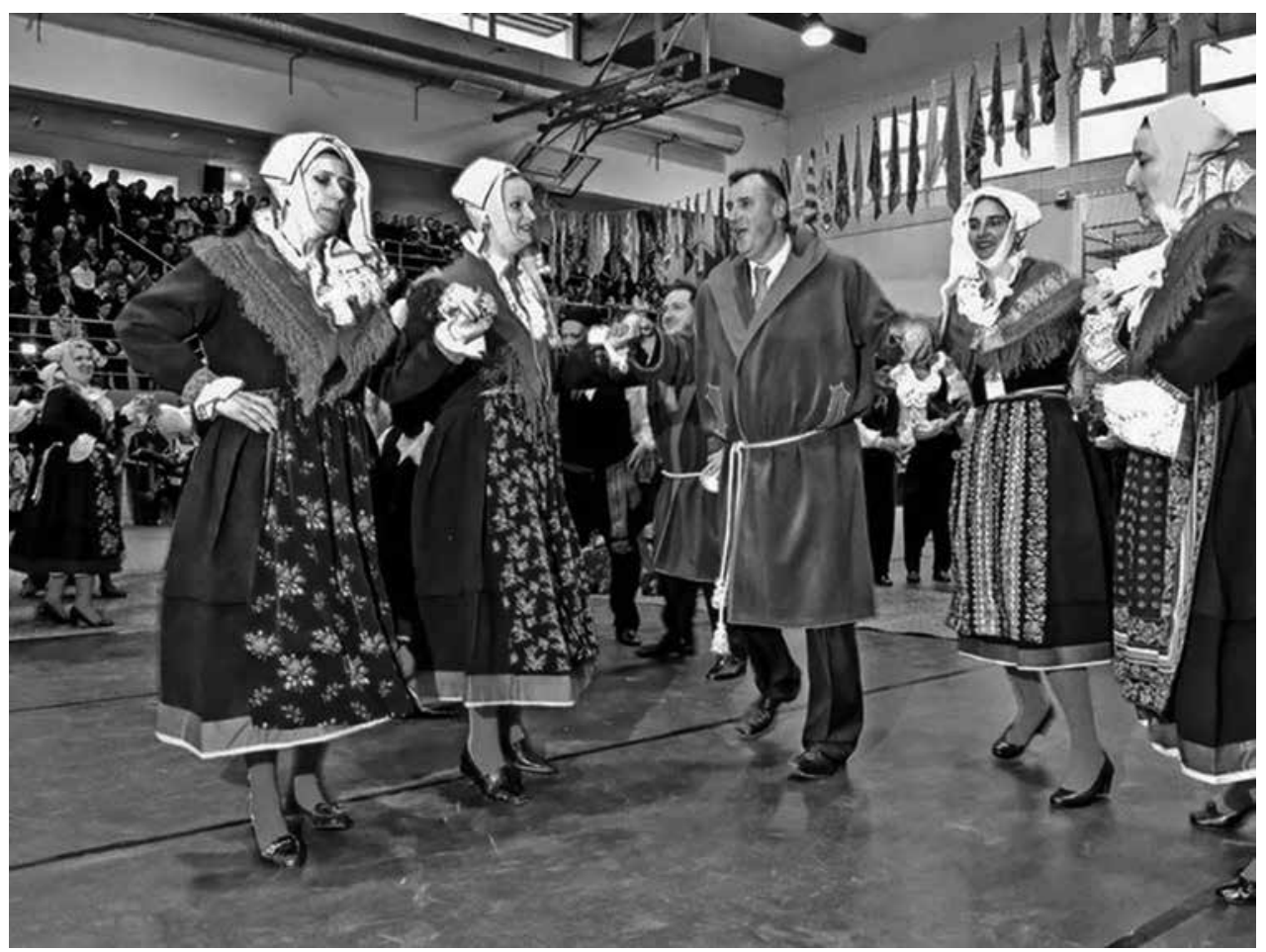

Kings tanac. Photo: Krunoslav Kaurić, Malinska, from Dubašljanski kolejani Facebook page <https://www.facebook.com/dubasljanski.kolejani/photos/pb.290870781084181. $-2207520000.1445566793 . / 365435496961042 /$ ?type $=3$ \&permPage $=1>$.

somewhat different manner, introducing into it certain figures of the Dobrinj tanac. Older Dubrašnica folk do not approve of such changes, but it is questionable if they would be able to influence the younger generation to 'correct' the differences that they have learnt 'mistakenly' because of then-existing circumstances. After all the groups had taken their turn in performing the tanac, everyone was invited to the largest Dubašnica tanac - from the oldest to the youngest, as well as all the members of the kolejani procession, so that there would be as many performers as possible. There were 320 performers in "the largest Dubašnica tanac ever" and the dance lasted for almost half an hour. ${ }^{25}$

During the kolejani dinner at the Hotel Malin, the music entertainment largely came from the sound of popular music and electro-acoustic instruments. However, at around 11.00 p.m. two young shawm (sopela) musicians stepped onto the small stage and, after playing some introductory notes of mantinjada they continued with some polkas and

25 I am referring here to the tanac in the narrow sense of the word, i.e. the dance itself. Owing to its size, the large, newly-built sports hall has enabled something that would have been inconceivable prior to its being built; nothing similar could have taken place in the open air. The local squares, the place, where the tanac had been danced in the open, were relatively small and it would not have been possible to perform a tanac with such a large number of dancers, even outdoors. 
mazurkas. ${ }^{26} \mathrm{~A}$ tanac was performed around half an hour later with the participation of all generations of the kolejani procession. Owing to the limited space for dancing in the hotel restaurant, the tanac could not be fully developed and only lasted for a relatively short time. Still, it symbolically marked the peak of the pir, and was followed by the guests being able to continue to be entertained with contemporary popular music.

\section{INTANGIBLE CULTURE IN THE DIGITAL AGE}

I recorded the koleda events in Dubašnica with my digital video camera during the fieldwork carried out on January 17-18, 2015. When I began to write this text I asked a colleague, Tomislav Galović, about whether he knew of any new or additional literature and published material. His immediate response was that I should look at the texts published on the website of the municipality of Dubašnica-Malinska that published general information and has links to the quarterly Naši zvoni in the pdf format. ${ }^{27} \mathrm{He}$ also made reference to the Facebook page of the Dubašljanski Kolejani Society and some YouTube clips. In addition to the field experiences and transcriptions of recorded material, these sources were also important for the interpretation.

The project for the revival of the koleda ritual, which was warmly welcomed by the people of Dubašnica after 25 years, is widely considered to have been an exceptional success. The excellent organization on the part of the society, which took the form of weekly meetings and the use of digital technology to facilitate communication and keep documentation up to date efficiently, has proven to be vital. The new documentation collected, along with the old data which was digitized in the meantime, is accessible thanks to the possibilities offered by technology. The local community was very keen to collect the data and post it on Facebook or upload it to YouTube, with their main interest being to share it among themselves.

When the broad circle of interested participants and onlookers are added to the mix, particularly with their comments on social network and accessible texts and articles online, a completely new field of study is opened up for researchers. Through developments in archive and field research, the area of electronic sources is conquering space and people with unbelievable speed. Under their influence, the habits of the local communities that are no longer defined by space are now changing or becoming augmented. Direct online communication allows even community members that have emigrated to flung parts of

26 Mantinjada is the most ceremonial part of playing on sopela instruments, and usually takes place at the beginning of an event or as announcement for something very important such as a wedding (Zebec 2005: 216). The name derives from the Italian matinatta or matinea and it is in slow tempo (Matetić-Ronjgov 1938: 1).

27 I very much appreciate the helpful suggestions provided by Galović and Kremenić to improve this text. 
the world but continue to have ties to their native land, customs and people, to engage and participate with each other, even if they are unable to do so in person. Their enthusiasm is sometimes even stronger because of their spatial relocation than that of people acting in their own space, and this has an "infectious" influence on the local folk.

Colleagues from the regional conservation section of the Ministry of Culture in Rijeka have supported the local community in the implementation of the koleda renewal project. In recognition of these customs as valuable examples of living heritage that are being renewed after a quarter of a century, coupled with the mobilization of the entire local community, representatives from the Ministry of Culture demonstrated their support through their visit and address to their hosts in Dubašnica. In keeping with everything that has been written by many authors, they supported the idea that the koleda is an example of heritage that is particularly deserving of attention from the wider community. Along with all that they have achieved alone with their organization and major engagement, the local communities have expectations that their koleda will be inscribed in the Register of Cultural Goods of the Republic of Croatia. Since through their own efforts they have managed to renew the ritual, they are certain to soon commence the procedure for inscription in the State Register. By enthusiastically renewing and maintaining their custom, the community has demonstrated how important the koleda is in expressing their identity. In doing so, the people of Dubašnica have demonstrated, despite this not being done publicly, that they have implemented protection measures in a highly organized, independent and systematic manner so that they can pass on this tradition to their young people. In this way, they have also met the basic criteria for the registration of intangible culture (Nikočević [et al] 2012).

There needs to be a discussion within the framework of the profession on the koleda ritual and the criteria for its inscription as heritage in the Register. Apart from the Dubašnica koleda, there also exists on the island of Krk the above-mentioned koleda in Gabonjin in which a king is also chosen, as well as a series of other koleda in other island settlements that do not involve a king being chosen. An assessment will have to be made on how this heritage should be registered and professionally and administratively cared for in the future. ${ }^{28}$

Although it may seem more logical to augment research of disciplines such as archaeology with digital aids because of the firm and unchanging material involved, the example put forward regarding research of the Dubašnica koleda demonstrates that those tools are also a considerable help to us when researching the living cultures that are the focus of

28 Drawing from existing sources, Galović states that apart from the koleda for St Stephen's Day on Krk, the ritual also takes place at Christmas (25.12.), New Year (1.1.) Twelfth Night (6.1.), and in honour of St Catherine's Day (25.11.), St Mandalina's (22.7.) and for the Assumption Day of the Virgin Mary (15.8.). Kremenić (2001) also dealt in detail with the koleda on the island. He mentioned the revival of the ritual in Omišalj in 2000, and in Kornić in 1991, where it had not taken place since 1963. He monitored and commented on its development because, as in Jurandvor, it had been organised every year since its renewal. The entire communities take part, even in those where a king is not chosen, and they are directly connected in the calendar with the Carnival customs that follow them (Zebec 2005: 165-166). 
ethnology, folklore research and cultural anthropology. ${ }^{29}$ With electronical communications technology and the possibilities of connecting local communities with experts and administration that were unconceivable until now, favourable outcomes are a certainty. Local people as bearer of tradition gets actively involved in its virtual presentation and at the same time its members are encouraged to collect archival material (cf. Niemčić 2015: 239). The activities carried out by experts in collecting field material are made so much easier by communication infrastructures such as digital repositories, as well as through websites, YouTube and social networks like Facebook. Although we have used computers for over two decades now, technology is developing so quickly that we are only just starting to discover its capacities and we learn about improvements made all the time. Even if, as researchers in music and dance, we know about digital humanities, we were not as involved in information technology as experts in the field. We are now at another crossroads where we need to not only work out how best to implement it as a technical tool but also to discuss its influence on our research in culture and epistemology.

Connecting local communities and cognoscenti with the administrative bodies that carry out the protection of cultural assets can be a thankless task if diverse and unyielding interests confront each other. ${ }^{30}$ However, in such cases, the successes achieved, such as research into costumes in Dubašnica, the revival of Glagolitic singing, the tanac and the traditional way of singing, also speak in support of the activities that local community can achieve with the help of experts.

\section{REFERENCES}

Bolonić, Mihovil. 1980. Otok Krk - kolijevka glagoljice [The Island of Krk - the Cradle of Glagolitza]. Zagreb: Kršćanska sadašnjost.

Bozanić, Anton. 2014. Dubašnica - povijesne mijene, drevna župa i iseljenici u New Yorku [Dubašnica - historical changes, ancient parish and emigrants to New York]. Malinska: Općina Malinska-Dubašnica, Glosa d. o. o. Rijeka.

Cerović, Zdenko. 2014/2015. Važnost očuvanja kulture, čimbenik opstojnosti ljudi [The importance of safeguarding culture, a factor of people's existance]. http://www.malinska.hr/pdf/dk-kultura.pdf (accessed August 2015).

Galović, Tomislav. 2004. O Dubašnici i njezinim ljudima: Prinosi za povijest dubašljanskoga kraja na otoku Krku [On Dubašnica and its dwellers: Contributions to the history of the Dubašnica Area on the island of Krk (Croatia)]. Krk: Adamić, Rijeka and Povijesno društvo otoka Krka.

29 During the meeting of European experts on digital humanities and its infrastructure (DARIAH), some colleague archaeologists and linguists expressed their surprise at how useful technology could be in researching living traditions.

30 For more detail on the various examples of heritage production throughout the world and the differences in opinion regarding the implementation of the UNESCO Convention for the Safeguarding of the Intangible Cultural Heritage see Proizvodnja baštine (Hameršak, Pleše and Vukušić 2013). 
Galović, Tomislav. 2013. Dubašnica Social Club of America Inc. (New York). Krčki zbornik 69: 205-225.

Galović, Tomislav. 2014. Ususret Dubašljanskim kolejanima [To meet Dubašljanski Kolejani]. Krčki val 3 (24), December: 24-25.

Gavazzi, Milovan. 1991. Godina dana hrvatskih narodnih običaja [Year on Croatian folk customs]. Zagreb: Hrvatski sabor kulture.

Gennep, Arnold van. 1960 (1908). The Rites of Passage. Chicago: University of Chicago Press.

Hameršak, Marijana, Iva Pleše and Ana - Marija Vukušić (eds.). 2013. Proizvodnja baštine: Kritičke studije o nematerijalnoj kulturi [Producing Heritage: Critical Studies on Intangible Heritage]. Zagreb: Institute of Ethnology and Folklore Studies. http://www.ief.hr/ZbornikProizvodnjaBastine (accessed August 2015).

Ivančan, Ivan. 1967. Narodni običaji korčulanskih kumpanija [The folk customs of the Korčula kumpanija]. Zagreb: Institut za etnologiju i folkloristiku.

“Kolejani”. Dnevnik [Daily news]. Kanal Ri. Novinar Larry Ambrozich. Emitirano 29. 12. 2014. https:// www.youtube.com/watch?v=Rm-MciUHrbo (accessed August 2015).

Kremenić, Damir. 2001. Koledve na Krku [Koledve on Krk]. Diplomska radnja/Graduating thesis. Filozofski fakultet Sveučilišta u Zagrebu. Odsjek za etnologiju.

Kremenić, Damir. 2015. Dubašljanske narodne nošnje [Folk costumes of Dubašnica]. Malinska: Općina Malinska-Dubašnica; Kornić: Katedra Čakavskog sabora.

Lozica, Ivan. 1990. Izvan teatra: Teatrabilni oblici folklora u Hrvatskoj [Out of theatre: Theatrabile forms of folklore in Croatia]. Zagreb: Hrvatsko društvo kazališnih kritičara i teatrologa.

Matetić-Ronjgov, Ivan. 1938. Opis narodnih plesova iz Omišlja. I. Verec. II. Tenec. III. Bakarska. Omišalj na otoku Krku [A description of folk dances in Omišalj]. ONŽO SZ 230 HAZU, Odsjek za etnologiju. Fotokopija. IEF rkp/ms 1574.

Milčetić, Ivan. 1917. Koleda u južnih Slavena: Na osnovi istoričkih vijesti, narodnih pjesama i običaja našega vremena [Koleda in the South Slavs: Based on historical news, folk songs and customs of our time]. Zbornik za narodni život i običaje 22: 1-124.

Milovčić, Ive. 1995. Dubašljanski narodni običaji [Folk customs of Dubašnica]. Narodni život i običaji Krka. Knjiga 2. Krčki zbornik 33. PI 27: 265-295.

Naša sloga [Our Union]. 1901. Koledva. (7), Pula 22. 1. 1901., ed. Stiepo Gjivić. http://otok-krk.org/krk/ hrvatska/ususret-dubasljanskim-kolejanima-2014.-2015 (accessed August 2015).

Naši zvoni: Glasilo opcine Malinska-Dubašnica [Our bells: The quarterly of Malinska-Dubašnica municipality]. http://www.malinska.hr/preuzimanje.html (accessed August 2015).

Niemčić, Iva. 2015. The Internet Presentation of the Intangible Cultural Heritage Based on the Example of Sword Dances in Croatia. In: Elsie I. Dunin (ed.), Dance-Narration-Heritage. 28th Symposium of the ICTM Study Group on Ethnochoreology 7-17 July 2014 Korčula, Croatia. Zagreb: ICTM Study Group on Ethnochreology, Institute of Ethnology and Folklore Research, 238-242.

Nikočević, Lidija (et al.). 2012. Kultura ili baština?: Problem nematerijalnosti/Culture or Heritage: The Problem of Intangibility. Etnološka tribina 42/35: 7-56; 57-112. http://hrcak.srce.hr/index. php?show=clanak\&id_clanak_jezik=138058 (accessed August 2015).

Pavačić, Ivan (ed.). 2005. Krčki festival 1935.-2005. [Krk Festival 1935-2005]. Krk: Centar za kulturu grada Krka i Grad Krk.

Šamanić, Josip. 2014. Mihojski kolejani [Kolejani of Miholjice]. Naši zvoni 18 (67) rujan: 12-13. 
Šamanić, Vinko. 1989. Eradikacija malarije od 1920. do 1941. godine [Malaria eradication 1920-1941]. Zdravstvo otoka Krka. Krckki zbornik 19: 143-149.

Škrbić, Nevena. 1999. Milčetićeva "Koleda u Južnih Slavena" i običaj biranja kralja ["Koleda in the South Slavs" and the custom of choosing the king by Milčetić]. Diplomska radnja. Filozofski fakultet Sveučilišsta u Zagrebu, Odsjek za etnologiju.

Trinajstić, Mladen. 2015. Prvi put nakon 25 godina: Veli pir za 400 dubašljanskih kolejana [The first time after 25 years: Grand feast for 400 kolejani in Dubašnica]. Novi list, 19. 1.2015. http://www.novilist.hr/Vijesti/Regija/Otoci/Prvi-put-nakon-25-godina-Veli-pir-za-400-dubasljanskih-kolejana (accessed August 2015).

Turčić, Ana. 2014. Pripreme za koledvu i veliki pir [Preparation for koleda and grand feast]. Krčki val 3 (24) prosinac: $26-27$.

Zebec, Tvrtko. 1995. O teorijah in metodah raziskovanja plesa [About the theories and metods in dance research]. Traditiones 24: 301-307.

Zebec, Tvrtko. 2005. Krckki tanci: Plesno-etnoloska studija = Tanac Dances on the Island of Krk: Dance Ethnology Study. Zagreb: Institute of Ethnology and Folklore Research; Rijeka: Adamić (Biblioteka Nova etnografija).

Zebec, Tvrtko. 2006. The Kolijani Ritual Event on the Island of Krk, Croatia: Continuity or Revival? Yearbook for Traditional Music 38: 97-107.

\section{KOLEDA ZA PRIHODNOST - PLESI TANAC ZA VSE GENERACIJE. NESNOVNA KULTURA V DIGITALNI DOBI}

Koleda je eno od imen za obredne obhode in skupino ljudi, kolejane, ki pri obhodu pojejo enako imenovane pesmi. Koleduje se večinoma v božično-novoletnem času, zato se ime koleda pogosto uporablja tudi za ta čas. Obhodnike, ki obiskujejo hiše, gospodarji obdarujejo, kolejani pa obdarujejo gospodarje, ki so potrebni pomoči. Izviri koled so predkrščanski, šege pa so se sčasoma pokristjanile in se ohranile, ker so se v zgodovinskem procesu vse do danes prilagajale in spreminjale. Samo z raziskovanjem dogajanja je v celoti mogoče razumeti poglavitni smisel, pravi pomen in sinkretizem kolede.

Posebnost kolede na Krku je izbiranje kralja in kraljice (prav tako moškega). Spremljali smo intenzivnost kolede na prehodu leta 2014 v 2015, da bi pojasnili pomen teh šeg za skupnosti vseh 18 vasi Dubašnice, tj. severozahodnega dela otoka Krka, kakor tudi poudarjanje globoko vsajenega kolektivnega spomina pri obnovi šege.

Prvi del poleg izbire kralja in kraljice na praznik sv. Štefana vsebuje tudi čas zbiranja in darovanja do praznika treh kraljev, drugi del pa je skupno praznovanje - pirovanje, navadno na nedeljo po svetih treh kraljih. Tanac, ki se pleše po maši, je dogodek, ki privabi številno občinstvo vseh generacij. Projekt obnove koledve, ki so ga z navdušenjem sprejeli po 25 letih, imajo vsi za izreden uspeh. K temu je poleg odlične organizacije zadruge "Dubošljanski kolejani", ki se je tedensko sestajala v organizacijskem odboru, prispevala tudi digitalna tehnologija. Pri obnovi so lokalno skupnost podprli tudi v regionalnem konservatorskem oddelku Ministrstva kulture in s tem pokazali, da je koleda dediščina, vredna posebne pozornosti tudi za širšo skupnost. Lokalna 
skupnost pričakuje, da bo koleda vpisana v "Registar kulturnih dobara Republike Hrvatske". Skupnost je z obnovo šege in osupljivim navdušenjem pri njeni predstavitvi pokazala, kako ji je koleda pomembna za izražanje identitete. Hkrati je dokazala, da je tudi zelo organizirano, samostojno in sistematično izpeljala zaščitne ukrepe, da se bo izročilo preneslo na mlade tudi takrat, ko ne bo javno vidno. S tem so ustregli poglavitnim merilom za registracijo nesnovne dediščine. Uporaba novih medijev in digitalne tehnologije v raziskovanju se je pokazala kot pomemben del interpretacije, posebej pa kot lahko dostopen vir podatkov v dokumentaciji. Podatke je mogoče brez težav posodabljati in zbirati. S tem je koleda dober zgled prenašanja šeg v prihodnost in novim generacijam, pri tem pa imajo tanci in tradicijska plesna znanja pomembno ritualno vlogo.

Dr. Tvrtko Zebec, Institute of Ethnology and Folklore Research Šubićeva 42, 10000 Zagreb, Croatia, zebec@ief.hr 